\title{
Credit Access through Warehouse Receipt System and Farm Productivity of Smallholder Coffee Farmers in Mbinga District, Tanzania
}

\author{
Matei E. Mapunda \\ Tanzania Institute of Accountancy \\ Tanzania \\ David G. Mhando \\ College of Social Sciences and Humanities \\ Sokoine University of Agriculture \\ Tanzania \\ Betty M. Waized \\ School of Agricultural Economics and Business Studies (SAEBS) \\ Sokoine University of Agriculture \\ Tanzania
}

\begin{abstract}
The Warehouse Receipt System (WRS) offers an opportunity to smallholder farmers by providing collateral guarantees to financial institutions to provide credit for agricultural inputs through their crops stored at the warehouses. The objective of this paper was to examine the contribution of agricultural inputs credit accessed through WRS on coffee farms productivity in Mbinga District, Tanzania. A household survey from a sample of 390 smallholder coffee farmers was conducted. Ordinary Least Squares (OLS) was used to examine the impact of WRS agricultural-credit on coffee yield. Study results show that credit accessed through WRS had a significant $(p \leq 0.05)$ and positive influence on coffee yield. Moreover, sex, years of schooling, and extension services had a significant effect on coffee yields. The intervention policies are needed in order to enable more farmers to access the WRS services, extension services, education and increasing women's participation in WRS in the study area.
\end{abstract}

Keywords: credit, farm productivity, warehouse receipt system, agricultural inputs credit, smallholder coffee farmers

\subsection{Introduction}

Agriculture plays an important role in the livelihoods of the majority of farmers in developing countries, Tanzania included; improved farm productivity remains an important goal in increasing income of farmers (URT, 2016). Farm productivity can either be improved through increase in output and inputs, with output increasing proportionately more than inputs, increases in output while inputs remain the same or decrease, or decrease in inputs while outputs remain the same (Olubiyoet al., 2009). The use of inputs for expanding outputs includes raising both the quality and quantity of inputs such as high yielding seed varieties, fertilizers, pesticides and improvement of productive land (Ajibolaet al., 2011).

The use of inputs for the purpose of expanding outputs is hampered by credit accessibility constraints imposed by financial institutions to farmers. Lack of access to credit is a challenge for many smallholder farmers in subSaharan Africa (SSA) to expand their production levels because most farmers cannot meet the minimum requirements of being creditworthy from financial institutions (Cooksey, 2010). Therefore, they are excluded from the formal credit market (Onumah, 2010). Since WRS provides an opportunity among farmers of accessing credit, this paper forms a base of informing stakeholders on the worthiness of agricultural inputs credit through the WRS in order to intervene for the betterment of farmers and the agricultural sector at large.

Access to credit and its use may affect farm productivity as farmers facing farm capital constraints would tend to use lower levels of agricultural inputs in their production activities compared to those not constrained (Feder et al., 1989; Petrick, 2004). 
Improved access to credit may therefore facilitate optimal input use and have a major impact on farm productivity as credit allows farmers to satisfy their cash needs induced by the farm production cycle and consumption requirements (Boucher et al., 2009). Moreover, factors such as socio-demographic characteristics of farmers, preexisting household resource endowment, and the surrounding physical, social and economic environment are considered to be significant in determining farm productivity (Nto and Mbanasor, 2011).

In acknowledging significance of credit in farm productivity and success of individual farmers, various actors like government and financial institutions of developing countries need to advocate the importance of accessing credit by smallholder farmers. Smallholder farmers are described as those with 2 hectares or less, they represent $80 \%$ of all farmers and contribute up to $90 \%$ of the production in some countries (Komarek, 2010). On the other hand, credit is a legal contract whereby one party receives resources or wealth from another party and promises to repay on a future date together with interest, whereby resources provided may be financial, goods or services (Simkovic, 2016). Others have defined credit as the ability of a customer to obtain goods or services before payment, based on the trust that payment will be made in the future (Guirkinger and Boucher, 2008; Abate and Orr, 2011).Credit in the context of this paper refers to finance or basic farming necessities or requirements such as seed, pesticides and fertilizer (agricultural inputs) that are given to farmers on loan basis.

Farm productivity refers to the output produced by a given level of input: It can also be stated as the ratio of the value of total farm output to the value of total input used in farm production (Chen, 2006; Ramailaet al., 2011; Banker et al., 2012). However, the average yield per hectare, which is commonly expressed in tons per hectare ( $\mathrm{t} / \mathrm{ha}$ ) is the most frequent measure of farm productivity (Wiebe et al., 2001). Measure of productivity can be partial or total (Ajibola, 2011). In theory total productivity is more useful for assessing performance of all inputs at once while partial productivity is useful in assessing worthiness of employing an additional unit of input (Ramailaet al., 2011). Thus, this study employed partial productivity for assessing the effect of each input in coffee farm productivity.

Although credit plays an important role in improving farm productivity, the lending policy of many financial institutions requires legally formalised physical assets to act as collateral to guarantee the credit (Onumah, 2012). Therefore, institutions such as banks are always unwilling to lend money to farmers because of the high risk involved in farming (Cooksey, 2010). In many developing countries, Tanzania included, farmers' assets are owned informally and thus creating difficulties to use as collateral for credit application from financial institutions (Kwadjo, 2000; Coulter and Onumah, 2002; Cooksey, 2010). This situation forces farmers to sell their produce immediately after harvest, and in most cases at lower prices (due to financial constraints) of which access to credit would have assisted to meet their financial needs (Poulton et al., 2010; IFAD, 2014). In principle, credit is an input used in production as well as a facilitator of the effectiveness of other production inputs (Madulu, 2011; Onumah, 2012). Improved access to credit may therefore facilitate optimal input use, leading to significant improvement in farm productivity. The realisation of importance of credit has necessitated the GoT to introduce the WRS, whereby in 2005, the Tanzanian parliament enacted the WRS Act of 2005 (URT, 2005). Since then the WRS has been considered as one of the ways used to channel credit to smallholder farmers, which allows the use of stocks as collateral for credit access (URT, 2005; Onumah, 2010; KENFAP, 2011).

The WRS is an arrangement aimed at providing services related to storage, access of credit and marketing of farmers' produce (URT, 2005). It allows farmers to extend the sales period of their produce while waiting for the crop prices to appreciate (URT, 2005; Komba, 2011). The system is meant to create a negotiation environment to farmers for forward markets forecast after having essential information needed to achieve win-win transactions between sellers and buyers (Lacroix and Varangis, 1996; Millinga, 2009; Komba, 2011; IFAD, 2014). A warehouse receipt (WR) is a document issued by warehouse operators to act as evidence that a specified commodity of a stated quantity and quality has been deposited at a location (s) by a named depositor (s) (Coulter et al., 2000). A depositor may be a producer, farmers' organisation, trader, exporter, processor or any individual or corporate body (Onumah, 2010). The receipt may be transferable, allowing transfer to a new holder a lender (where the stored commodity is pledged as security for a loan) or trade counter-party which entitles the holder to take delivery of the commodity upon presentation of the warehouse receipt at the warehouse (Onumah, 2003).

Even though the WRS is considered an important element in reducing constraints facing farmers in accessing agricultural inputs through provision of security for accessing credit by smallholder farmers, yet research findings show that farmers have some positive and negative perceptions towards WRS. 
For instance, Mtanda (2015) claims that about 63\% of cashewnut farmers in Tandahimba District, Mtwara Region in Tanzania had a negative perception towards the WRS. Similarly, in Newala District, Mtwara Region in Tanzania it was found that $67.9 \%$ of the farmers showed discontent with the contribution of WRS towards crop production and productivity for their farms (UNIDO, 2011). The major reason was dishonest among WRS staff. However, a study conducted by Komba (2011) in Mbinga District revealed that after the introduction of the WRS there was an increase in output in coffee production from 9000 metric tons in 2011/12 to 12000 metric tons in 2014/15. However, Komba's (2011) findings did not tell exactly if accessing credit through the WRS for agricultural inputs had contributed to a significant increase in coffee yields. Also, studies by Mtanda (2015) and UNIDO (2011) did not investigate the WRS agricultural inputs credit access effects on cashewnut yields or an impact on farm production and productivity. Hence, there is little or inadequate information regarding the effect(s) of credit access through WRS on crop production and productivity. Therefore, this study was conducted to fill this knowledge gap by investigating the effect of agricultural inputs credit access through the WRS on farm production and productivity of smallholder coffee farmers in Mbinga District.

\section{Theoretical Framework}

The study used the theory of farm production to understand how agricultural inputs credit influences farm productivity. The theory asserts that output per unit input supplied depends on the factor inputs used (financial and human inputs) (Ellis, 1992). The human input is a function of demographic characteristics e.g. age, education level, household size, sex and the use of irrigation system in farming (Ajibolaet al., 2011). The farm inputs include capital (credit to purchase seeds, fertiliser and pesticides), labour and land (farm size); whereby credit raises productivity by increasing the ability to purchase agricultural inputs; education, labour, extension services, age, household size, the use of irrigation system and sex significantly affect production performance either positively or negatively (Anyaegbunamet al., 2010). The theory portrays that farmers who use inputs depending on the quality and quantity are expected to have higher output and hence higher productivity than those who do not.

\section{Methodology}

\subsection{The study area}

This study was conducted in Mbinga District, Ruvuma Region in the Southern part of Tanzania from May to October 2014. The area was selected for the reason that the WRS services were accessed by farmers through membership to Agricultural and Marketing Cooperative Societies (AMCOS) or farmers' groups (FGs). In Mbinga District, 95\% of coffee is produced by smallholder farmers (Basehert, 1972; Itani, 1998), this forms one of basis for selecting the district for study. The major source of income of the indigenous people who are smallholder farmers in the district is coffee and farmers access WRS services through membership in AMCOS or FGs. Therefore, the study area provided a suitable place for studying the WRS and farm productivity of smallholder farmers.

A cross-sectional research design was used and was considered appropriate because of the nature of information required for this study, by allowing data to be collected at one point in time from different groups of respondents. Moreover, it was also easier and adequate to organize and relate the data collected at a single point for processing, analysis and presentation (Olaitan, 2006). The target population was coffee farmers in Mbinga District.The sampling frame was all coffee farmers' users of the WRS services. The selection of respondents was based on a cluster sampling of two zones (Matengo highlands and the lowlands). Using a simple random sampling of numbers generated in MS Excel, proportionally, a total of 390 respondents from AMCOS (230) and FGs (160) from each zone were randomly selected from a register provided by the District Agricultural, Irrigation and Cooperative Officer (DAICO). The Yamane (1967) formula gave, 4 AMCOS and 4 FGs from 21 AMCOS and 21 FGs registered in the district (Appendix 1).Since AMCOS had more coffee farmers (2304) than FGs (1596) (Appendix 1).

\subsection{Model and estimation method}

In literature there are numerous measurements of agricultural farm productivity. In this study farm productivity was calculated by computing a ratio of output produced per farm size cultivated by a farmer. The Cobb-Douglas production function (Cobb and Douglas, 1928) was used to study the effects of credit access through the WRS and farm productivity of smallholder coffee farmers in Mbinga District. Similar empirical studies such as that of Carter (1989), Banker et al. (2012) and Malate et al. (2013) used similar function form specified as shown below. 
$Y_{i}=T_{i} L_{i}^{\beta} W_{i}^{a} e^{\eta_{i}}$

Where, $Y_{i}=$ total coffee production measured in kilograms; $L_{i}=$ cultivated area under coffee in hectares; $W_{i}=$ number of labour used in coffee production; $T_{i}=$ total factor productivity expressing efficiency of household in transforming farming inputs into coffee; $\alpha$ and $\beta$ are unknown parameters to be estimated and $\eta_{\dot{i}}=$ error term and

Dividing by equation (1) by and applying natural logarithm the expression become as shown in equation (2).

Since household specific characteristics affects output through efficiency of them transforming agricultural inputs to outputs therefore the total factor production was estimated as shown in equation (3).

Where, = household characteristics affecting total factor productivity, = unknown parameters to be estimated and $=$ disturbance term and

Combining equation (2) and (3), equation (4) is obtained which is linear in parameters and can be estimated using Ordinary Least Squares (OLS) (Pallant, 2007; Gujarati and Sangeetha, 2007).

Where, and $\quad$ and and $=\mathrm{a}$ dummy variable of farmer receiving credit through the WRS $\quad(1=$ yes; $0=$ no $) ; \quad=$ farmer's age in years; = a dummy variable of farmer's sex $\quad(1=$ male, $0=$ female $) ; \quad=$ a dummy variable of farmer receiving extension service $\quad(1=$ yes, $0=$ no $)$ and $\quad=$ a dummy variable of farmer using irrigation $(1=$ yes, $0=$ no $)$. Descriptions of the variables used in the model for regression analysis are presented in Table 1.

Table 1: Description of variables used in the model

\begin{tabular}{|c|c|c|}
\hline Variables & Description & $\mathbf{E}$ \\
\hline \multicolumn{3}{|l|}{ Dependent Variable } \\
\hline Yield & Coffee production in kilograms per hectare & \\
\hline \multicolumn{3}{|l|}{ Explanatory Variables } \\
\hline $\begin{array}{l}\text { Household receiving credit through the WRS } \\
(1=\text { Yes, } 0=\text { No) }\end{array}$ & $\begin{array}{l}\text { Dummy variable for household receiving credit } \\
\text { through the WRS }\end{array}$ & + \\
\hline Household head years of schooling & Number of years spend in formal education & + \\
\hline Household head age & Number of years of head of household & + \\
\hline $\begin{array}{l}\text { Household head sex } \\
(1=\text { Male, } 0=\text { Female })\end{array}$ & $\begin{array}{l}\text { Dummy variable for indicating sex of the head of } \\
\text { household }\end{array}$ & + \\
\hline $\begin{array}{l}\text { Household using irrigation } \\
(1=\text { Yes, } 0=\text { No })\end{array}$ & $\begin{array}{l}\text { Dummy variable for household using irrigation to } \\
\text { the coffee farm }\end{array}$ & + \\
\hline $\begin{array}{l}\text { Household had extension service } \\
(1=\text { Yes, } 0=\text { No })\end{array}$ & $\begin{array}{l}\text { Dummy variable for household receiving extension } \\
\text { service }\end{array}$ & + \\
\hline Household coffee cultivated area & Number of hectares under coffee cultivation & + \\
\hline Household labour per coffee cultivated area & Number of labour used per hectare of coffee & - \\
\hline
\end{tabular}

Coefficient of a dummy variable receiving credit through the WRS is expected to have a positive sign since credit from WRS enables farmers to acquire yield through enhanced agricultural inputs. Coefficient of household head education is expected to have a positive sign since the higher the education the higher the ability of a farmer to acquire, synthesize and utilize information which will lead to better use of agricultural inputs. 
Coefficient of household age is expected to have a positive sign because as age increases a farmer accumulates more knowledge and skills which affect productivity positively. Coefficient of sex is expected to have a positive sign because in African societies men are privileged when it comes to access of information, capital, land and other resources while women are marginalized on those areas (Abdul at al.,2010). The coefficients of coffee cultivated area and labour per hectare are expected to be positive. The positive sign are due to timely credit services available to AMCOS and FGs members, the confidence of members on lending agencies, accessibility of loans, and agricultural inputs stimulate production (Karunakaran and Mekonnen, 2013; Mengistu, 2015).

\section{Results and Discussion}

4.1 Socio-economic characteristics of respondents

The socio-economic characteristics of respondents' results are as presented in Table 2.

Table 2: Socio-economic characteristics and credit accessed through the WRS

\begin{tabular}{|c|c|c|c|c|c|c|}
\hline \multirow[t]{2}{*}{ Variable } & & & \multicolumn{3}{|c|}{$\begin{array}{l}\text { Percentage of farmers accessed } \\
\text { agricultural inputs credit through the }\end{array}$} & \multirow[t]{2}{*}{ P-value } \\
\hline & & & No $(n=187)$ & Yes $(n=203)$ & & \\
\hline \multirow{2}{*}{ HH head sex } & Female & & 9.2 & 9.2 & 18.5 & 0.399 \\
\hline & Male & 38.7 & & 42.8 & 81.5 & \\
\hline \multirow[t]{2}{*}{ HH head age } & 50 years and above & & 12.6 & 16.4 & 29.0 & 0.247 \\
\hline & $\begin{array}{l}\text { Less than } 50 \\
\text { years }\end{array}$ & & 35.4 & 35.6 & 71.0 & \\
\hline $\mathrm{HH}$ received & No & & 29.0 & 22.3 & 51.3 & 0.010 \\
\hline extension & Yes & & 19.0 & 29.7 & 48.7 & \\
\hline \multirow[t]{2}{*}{$\mathrm{HH}$ used irrigation } & No & & 47.4 & 36.4 & 83.8 & 0.000 \\
\hline & Yes & & 0.5 & 15.6 & 16.2 & \\
\hline $\begin{array}{l}\text { HH head with } \\
\text { primary school }\end{array}$ & Yes & & 31.5 & 29.2 & 60.8 & 0.052 \\
\hline $\begin{array}{l}\text { HH head with } \\
\text { secondary school }\end{array}$ & Yes & & 14.4 & 20.8 & 35.1 & 0.040 \\
\hline $\begin{array}{l}\text { HH head with } \\
\text { post-secondary } \\
\text { school }\end{array}$ & Yes & & 1.0 & 1.5 & 2.6 & 0.010 \\
\hline $\begin{array}{l}\text { HH head with no- } \\
\text { formal education }\end{array}$ & Yes & & 1.0 & 0.5 & 1.5 & 0.305 \\
\hline
\end{tabular}

The results in Table 2 show that $81.5 \%$ of the respondents were male headed households and only $18.5 \%$ were female headed ones. The difference was attributed by the fact that Mbinga District is a patrilineal society (Baseheart, 1972). With regards to sex, results indicated that in the study area there was no significant difference within sex group between those who accessed agricultural input credit through the WRS and those who did not. This implies that accessing agricultural input credit through WRS is not gender sensitive and that WRS offers equal opportunities to both males and females promising prosperity of the system and enhancement of increased coffee production. This finding is contrary to Doss (2011) who argued that opportunities of farm production facilitations including credit for communities in African societies including Tanzania are characterised by male dominance system due to taboos that marginalize women, which make them less productive in the end.

Regarding the age of household head study results show that $71.0 \%$ of the respondents were less than 50 years of age while $29 \%$ were 50 years and above, however, there was no statistical difference between farmers who received agricultural inputs credit through the WRS and those who did not by age. Implying age is not a determining factor for accessing agricultural inputs credit through WRS.

Nonetheless, the WRS was dominated by productive age group farmers (50 years of age or less). URT (2007) describes the age group between 18 and 50 years as a productive age group. This means effective WRS could trigger high coffee production in coffee industry as at present the results have shown that across age groups the dominance of coffee production was of productive age group. 
Based on education of the respondents, results in Table 4.2 show that about $61 \%$ of the respondents had primary school education, $35 \%$ had secondary education, and about $3 \%$ had post-secondary education while about only $2 \%$ did not have any formal education. Hence, the majority of the respondents had formal education, and within formal education groups there was statistically significant difference between those who accessed agricultural inputs credit through the WRS and those who did not. This result of education level in relation to the WRS implies that farmers with more formal education tended to be more aware of WRS services such as credit, storage, and market unlike farmers with less. Although it is a fact that the effects of education take time to be revealed in a society it is also a fact that productive households tend to have more people with formal education (Temuet al., 2005). Therefore, due to that, it is expected that farmers with formal education will be more productive than households without it.

Results show further that, about $49 \%$ of the respondents had access to extension services, while $51 \%$ of the respondents did not; and between the two groups there is statistically significant difference. That infers that access to agricultural inputs credit should move in unison with provision of extension services to the famers so as to promote the agricultural production in terms of technology dissemination (new varieties, input use, farm implements and technical knowhow) (Temuet al., 2011). It advocates further the importance of improving the extension service department in the district. Moreover, $16 \%$ of the respondents were irrigating their crop, about $84 \%$ did not practice irrigation on their farms; and inferential statistics indicated that there is no statistically significant difference between those farmers who accessed agricultural inputs credit through the WRS and those who did not. This suggests that agricultural inputs credit brought insignificant contribution to the improvement of irrigation scheme in the district. In order to improve coffee production and the fact that irrigation scheme is a capital intensive (Itani, 1998) and farmers who accessed agricultural inputs credit through WRS were less than a quarter of the respondents $(16 \%)$, it raises a concern of having a special credit system through the WRS for irrigation scheme.

\subsection{Average coffee production, cultivated area, and labour use}

The average coffee production in a season was about $535 \mathrm{~kg}$ and $486 \mathrm{~kg}$ for the respondents who used the credit through WRS and those who did not respectively (Table 3). In addition, harvested coffee per hectare ranged from approximately $202 \mathrm{~kg}$ to $244 \mathrm{~kg}$ for those respondents who did not use agricultural inputs credit through the WRS and those respondents who used it respectively.

Table 3: Average coffee production, cultivated area, and labour use

\begin{tabular}{llllll}
\hline & \multicolumn{2}{l}{$\begin{array}{l}\text { Received agricultural } \\
\text { inputs credit through WRS } \\
(\mathbf{n = 2 0 3 )}\end{array}$} & \multicolumn{2}{l}{$\begin{array}{l}\text { Did not receive } \\
\text { agricultural inputs } \\
\text { credit through WRS } \\
\text { (n=187) }\end{array}$} & p-value \\
Mean & Mean & SD & SD & \\
\hline Variable & 534.8 & 155.8 & 485.6 & 148.0 & 0.002 \\
\hline $\begin{array}{l}\text { Average total coffee harvested } \\
\text { (kg/season/hectare) }\end{array}$ & & & & & \\
Average coffee harvested (kg/hectare) & 244.3 & 195.6 & 201.7 & 149.8 & 0.017 \\
Area cultivated for coffee (hectares) & 3.0 & 2.0 & 3.0 & 1.9 & 0.991 \\
Labour used in coffee farm (man-days) & 104.2 & 83.0 & 98.9 & 76.4 & 0.698 \\
\hline
\end{tabular}

Independent t-test statistics showed that in both cases there is significant difference in coffee production between respondents who used agricultural inputs credit through the WRS and those who did not. Also, the findings show that there were no significant differences in coffee cultivated area as well as total labour used in coffee production between those who were using agricultural inputs credit accessed through the WRS and those who were not. The findings advocate to the Mbinga District Agriculture, irrigation and Cooperative Officer (DAICO) to strengthen the use of WRS services such as agricultural inputs credit to help farmers increase coffee production.

The average productivity was great about $244 \mathrm{~kg} / \mathrm{ha}$ to farmers who used agricultural inputs credit through the WRS relative to non-users whose productivity was $202 \mathrm{~kg} / \mathrm{ha}$. This finding supports the theory of farm production that the use of agricultural inputs increases output per unit of land depending on the input quality and quantity (Banker et al., 2012). 


\subsection{Farm productivity of smallholder coffee farmer and WRS}

Table 4: Farm productivity of smallholder coffee farmer and WRS

\begin{tabular}{llc}
\hline Variables & Coefficients & \\
\hline Household receiving credit through WRS $(1=$ Yes, $0=$ No) & 0.104521 & 0.012 \\
Household head years of schooling & 0.015303 & 0.018 \\
Household head age & -0.002400 & 0.255 \\
Household sex $(1=$ Male, 0 = Female $)$ & -0.118150 & 0.019 \\
Household coffee cultivated area & -0.745439 & 0.000 \\
Household labour per coffee cultivated area & 0.198606 & 0.000 \\
Household using irrigation $(1=$ Yes, 0 = No) & 0.000003 & 0.999 \\
Household had extension service $(1=$ Yes, 0 = No) & 0.136724 & 0.001 \\
Constant term & 5.481695 & 0.000 \\
\hline & & 390 \\
Prob > F & & 118.43 \\
R-squared & & 0.000 \\
\hline
\end{tabular}

The R-squared of 0.7132 shows that the regression model explained about $71 \%$ of the variation of the response data. The F-statistic with $\mathrm{p}$-value $=0.000$ implies that the coefficients of explanatory variables were jointly not equal to zero. The coefficient of the farmer receiving credit through the WRS was positive and highly significant. Holding all other factors that influence coffee yield constant, coffee farmers who received agricultural inputs credit through the WRS had a yield of about 11\% higher compared to those who did not. The output increased at a greater proportionate for farmers accessed agricultural inputs credit through the WRS than for those who did not. The WRS agricultural inputs credit brought a significant increase in the coffee farm productivity. The results are in line with the findings reported earlier by Rosari et al. (2013) that a unit increase in credit used in farm production as an input resulted in 2.90 units increase in output. Moreover, Kayunzeet al. (2011) argue access to credit promotes agricultural productivity and subsequently reduce poverty and increase their wellbeing. This indicates that the use of WRS agricultural inputs credit increases yield to coffee farmers.

Furthermore, a male headed household had about $12 \%$ yield lower than that of a female headed household which is contrary to what was expected. The reason is Matengo tribe in Mbinga District is a patrineal one and women are fully engaged in agriculture relative to men. The argument is supported by Kayunzeet al. (2011) they urged that in Tanzania, female smallholders dominate production in the agricultural sector; and therefore, are important drivers of economic growth and poverty reduction. Suggesting empowering women in ownership of land in agriculturewould lead to the growth coffee production through WRS. The coefficient of years of schooling (education level) of the head of household had a significant positive effect on yield whereby an additional year of schooling (level of education) increased yield by about $2 \%$. The coefficient of household having access to extension services had a significant positive relationship with yield whereby household that had access to extension services registered about $14 \%$ more yield compared to those households with no access to extension services. The findings indicate that technological innovations such as improved seeds, use of fertilisers and other important novelties if adopted by farmers may trigger the coffee farm productivity in the district.

The coefficients of coffee cultivated area and farm labour estimate exhibit decreasing return to scale. A percentage increase in coffee cultivated area and labour leads to $0.3 \%$ increase in coffee production. This suggests that under given household sizes farmers could not increase coffee production by expanding their farm sizes. This suggestion is practical in Mbinga District due to scarcity of land (Itani, 1998).

\section{Conclusions}

The theory of farm production was supported in this paper. The theory propounds that farmers who use inputs are expected to have higher output and hence higher productivity than those who do not based on their demographic characteristics.Conclusively, the influence of credit in the form of agricultural inputs accessed through the WRS was significant. 
Other variables such as sex, farm size, education, labour, and extension services had significant impact on coffee farms productivity. However, age and irrigation had insignificant impact. The significant variables call for more WRS improvement in order to increase coffee farms productivity.

The following recommendations are suggested to the stakeholders in coffee sector for improving coffee productivity through the WRS: (1) Creation of an enabling environment for the WRS to work better relative to the current one, (2) Strengthening the availability of agricultural inputs credit through the WRS to increase coffee production. It is advised to strengthen the financial intermediaries for that matter, (3) Putting more efforts to support extension services so as to enable farmers get equipped with new innovation if any in coffee farming. This move will increase farm production and improve the income of farmers. Intervention policies that will increase participation of women in coffee production will positively contribute to coffee farm yield in the study area. Moreover, since credit was significant, and the objective of the paper was to examine the effect of credit on the coffee farm productivity, more research is needed to include panel data to study trend and broad outlook of the matter.

\section{References}

Abate, T. and Orr, A. (2011). Fremont Investment and Loan. Journal of Development Economics 14:13-40.

Abdul, B., Salami, A. and Kamara, B. (2010). Smallholder Agriculture in East Africa, Trends, Constraints and Opportunities. Working Papers Series No 105. African Development Bank, Tunis, Tunisia. 52pp.

Ajibola, K., Kuku, O. and Liverpool, L. (2011). A Review of Literature on Agricultural Productivity, Social Capital and Food Security in Nigeria. International Food Policy Research Institute. Abuja. 54pp.

Anyaegbunam, H., Okoye, C., Asumugha, G., Ogbona, M., Madu, T., Nwakor, N. and Ejechi, M. (2010). Labour productivity among smallholder cassava farmers in South East agro ecological zone Nigeria. African Agricultural Resources 5(21): 2882-2885.

Banker, R. D., Datar, S. M. and Kaplan, R. S. (2012). Productivity measurement and management accounting. Journal of Accounting, Auditing and Finance 5: 528-554.

Baseheart, H. (1972). Traditional History and political change among the Matengo of Tanzania. Africa 42: 87-97.

Boucher, S. R., Guirkinger, C. and Trivelli, C. (2009). Direct elicitation of credit constraints: Conceptual and practical issues with an application to Peruvian agriculture. Economic Development and Cultural Change 57(4): 609-640.

Carter, M. R. (1989). The impact of credit on peasant productivity and differentiation in Nicaragua. Journal of Development Economics 31(1): 13-36.

Chen, W. (2006). Productivity Growth, Technical Progress and Efficiency Change in Chinese Agriculture: 19902003. Journal of China Rural Survey 1: 18-23.

Cobb, C. W. and Douglas, P. H. (1928). A theory of production. American Economic Review 18(1): 139-165.

Cooksey, B. (2010). Marketing reform? The rise and fall of agricultural liberalisation in Tanzania. Development Policy Review 21(1): 67-91.

Coulter, J. P. and Onumah, G. E. (2002). The role of warehouse receipt systems in enhanced commodity marketing and rural livelihoods in Africa. Food Policy 27(4): 319-337.

Coulter, J., Sondhi, J. and Boxall, R. (2000). The Economics of Warehousing in Sub-Saharan Africa. African Review of Money, Finance and Banking. pp97-114.

Doss, C. (2011). The Role of Women in Agriculture. Agricultural Development Economics 2(11): 1-48.

Ellis, F. (1992). Peasant Economics: Farm Household and Agrarian Development. Wye Studies in Agricultural and Rural Development. Cambridge University Press, UK. 122pp.

Feder, G., Lau, L. J., Lin, J. Y. and Xiaopeng, L. (1989). Agricultural credit and farm performance in China. Journal of Comparative Economics 13(4): 508-526.

Guirkinger, C. and Boucher, S. (2008). Credit constraints and productivity in Peruvian agriculture. Agricultural Economics 39(3): 295-308. 
Gujarati, D. and Sangeetha, N. (2007). Basic Econometrics. 4th Edition, Tata McGraw-Hill, New Delhi. 1072pp. IFAD (2014). A framework for Linking Small Farmers to Markets IFAD and The United Republic of Tanzania Prime Minister's Office (2014). Agricultural Marketing Systems Development Scheme. Completion Report. 5pp.

Itani, J. (1998). Evaluation of an indigenous farming system in the Matengo Highlands, Tanzania, and its sustainability. African Study Monographs 19: 55-68.

Karunakaran, R. and Mekonnen, A. (2013). Study on the economic contributions of coffee cooperatives in Yirgacheffe Woreda, Gedeo Zone, Snnpr, Ethiopia.Internatinal Journal of Commerce Management Research 1: 2.

Kayunze, K. A., Maro, F. and Mashindano, O. (2011). Agricultural growth and poverty reduction in Tanzania 2000-2010. Working Paper No. 2. Where has agriculture worked for the poor and what can we learn from this? 40pp.

KENFAP (2011). The role of Warehouse Receipt System and Financial Services in Improving Produce Marketing by Smallholder Farmers in Kenya. KENFAP.Kenya. 52pp.

Komarek, A. (2010). The determinants of banana market commercialization in Western Uganda. African Journal of Agricultural Research 5(9): 775. [http://www.academicjournals.org/AJAR] site visited on 15/09/2015.

Komba, L. (2011). Market Position of Coffee Farmers in the Coffee Supply Chain: A Case Paper of Mbinga, Tanzania. Lambert Academic Publishing, ISBN 3844308636, 9783844308631. 76pp.

Kwadjo, G. T. M. (2000). Inventory Credit: A Financial Product in Ghana. Paper presented at Conference on Advancing microfinance in rural West Africa, Bamako, February 22-25, 2000.

Lacroix, R. and Varangis, P. (1996). Using Warehouse Receipts in Developing and Transition Economies Finance and Development 33(3).

Madulu, R. B. (2011). Improving access to credit for paddy farmers through warehouse receipt-based agricultural marketing system in Tanzania. African Crop Science Journal 10: 37-39.

Malate, A., Mlay, G. and Zavale, H. (2013). Determinant of Labour Productivity for Smallholder Maize Production in Mozambique. Eastern and Southern Africa Journal of Agricultural Economics and Development 10: 81-100.

Mengistu, M. M. (2015). Assessing the performances of coffee marketing cooperatives in yirgacheffe woreda, gedeo zone, snnprs, Ethiopia.International Journal of Community Cooperative Study 3(3): 30-43.

Millinga, M. (2009). Empowering farmers in Tanzania through the warehouse receipt system. IFAD report. Tanzania. 4pp.

Mtanda, A. M. (2015). Farmers' attitude towards Warehouse Receipt System in Newala District, Tanzania. Dissertation for Award of Master Degree at Sokoine University of Agriculture, Morogoro, Tanzania. 36pp.

Nto, P. O. and Mbanasor, J. A. (2011). Productivity in agribusiness firms and its determinants in Abia State, Nigeria. Journal of Economics and International Finance 3(12): 662-668.

Olaitan, M. A. (2006). Finance for small and medium enterprises: Nigeria's agricultural credit guarantee scheme fund. Journal of International Farm Management 3(2): 1-9.

Olubiyo, S. O., Hill, G. P. and Webster, J. P. (2009). Econometric Analysis of the Impact of Agricultural Insurance on Farming Systems in the Middle Belt, Nigeria. African Journal of Food Agriculture Nutrition and Development 9(6): 1406-1418.

Onumah, G. (2003). Improving Access to Rural Finance through Regulated Warehouse Receipt Systems in Africa.Paper Presented At Conference on "Paving the Way Forward for Rural Finance: An International Conference on Best Practices, Washington, 2-4 June. 
Onumah, G. (2010). Implementing Warehouse Receipt Systems in Africa Potential and Challenges. Paper prepared for the Fourth African Agricultural Markets Program Policy Symposium, organized by the Alliance for Commodity Trade in Eastern and Southern Africa (ACTESA) of the Common Market for Eastern and Southern Africa (COMESA), Lilongwe, Malawi, September 6-7, 2010. 20pp.

Onumah, G. E. (2012). Warehouse Receipts and Securitisation in Agricultural Finance to Promote Lending to Smallholder Farmers in Africa: Potential Benefits and Legal/Regulatory Issues. Uniform Law ReviewRevue de droituniforme17(1-2): 351- 367. [http://dx.doi.org/10.1093/ulr/17.1-2.351] site visited on $31 / 06 / 2016$.

Pallant, J. (2007). Survival Manual: A Step by Step Guide to Data Analysis SPSS for Windows, 3rd edition. New York. pp34-42.

Petrick, M. (2004). Farm investment, credit rationing, and governmentally promoted credit access in Poland: A cross-sectional analysis. Food Policy 29(3): 275-294.

Poulton, C., Dorward, A. and Kydd, J. (2010). The Future of Small Farms: New Directions for Services, Institutions, and Intermediation. World Development, Elsevier 38(10): 1413-1428.

Ramaila, M., Mahlangu, S. and Toit, D. (2011). Agricultural Productivity in South Africa: Literature Review. Department of Agriculture, Forestry and Fisheries.South Africa. 27pp.

Rosari, B., Sinaga, B., Kusnadi, N. and Sawit, M. H. (2013). The impact of Credit and Capital Supports on Economic Behavior of Farm Households: A Household Economic Approach. International Journal of Food and Agricultural Economics 19(2): 81-90.

Simkovic, M. (2016). What Can We Learn from Credit Markets?. Proceedings of the 93rd Annual Meeting of the American Law Institute.Washinton DC. 38pp.

Temu, A., Manyama, A., Mgeni, C., Langyintuo, A. and Waized, B. (2011). Characterization of Maize Producing Households in Manyoni and Chamwino Districts in Tanzania. The International Maize and Wheat Improvement Center. Nairobi. 22pp.

Temu, A., Nyange, D., Mattee, A. and Kashasha, L. (2005). Assessing rural services, infrastructure and their impact on agricultural production, marketing and food security in Tanzania: Tanzania Development Gateway.

[http://www. tanzaniagateway.org/docs/AssessingRuralServicesIandInfrastructureonAgriculturalProduction_Tanzania. pdf] site visited on 27/2/2017.

UNIDO (2011). Tanzania's Cashew Value Chain. A diagnostic annual report, United Nations Industrial Development Organization, Vienna, Austria. 66pp.

URT (2005). The Warehouse ReceiptActof 2005. Government Printers. Dar es Salaam, Tanzania. 24pp.

URT (2007). Tanzania National Youth Development Policy (TNYDP), Ministry of Labour, Employment and Youth Development, Dar es Salaam. 14pp.

URT (2016). National Five Year Development Plan 2016/2017-2020/2021: Nurturing Industrialization for Economic Transformation and Human Development. Ministry of Finance and Planning. 293pp.

Wiebe, K. D., Soule, M. J. and Schimmelpfennig, D. (2001). Agricultural Productivity for Sustainable Food Security in Sub-Saharan Africa. In: AgriculturalInvestment and Productivity in Developing Countries. Zepeda, L. (ed), FAO, Rome. 29pp.

Yamane, T. (1967). Statistics. An Introductory Analysis. 2nd Edition, Harper and Row, New York. 38pp. 


\section{Appendix 1: Sampling methods}

\begin{tabular}{|c|c|c|c|}
\hline Sample members & Population & $\begin{array}{ll}\begin{array}{l}\text { Number } \\
\text { respondents }\end{array} & \text { of } \\
\end{array}$ & Sampling method \\
\hline Highland area AMCOS & 12 & 1 AMCOS & \multirow{14}{*}{$\begin{array}{l}\text { The sample was randomly picked } \\
\text { from the villages in low and high } \\
\text { land zones using a table of } \\
\text { random numbers generated in } \\
\text { excel. The sample size used } \\
\text { formulae as below. } \\
\text { 1. Sample size formula } \\
\text { n } \\
=\text { sample size, } \\
\mathrm{N}=\text { population, e = an error }(\mathrm{e}= \\
0.05)\end{array}$} \\
\hline Lowland area AMCOS & 9 & $1 \mathrm{AMCOS}$ & \\
\hline Highland area Farmers' Group & 8 & 1 F. GROUP & \\
\hline Lowland area Farmers' Group & 13 & 1 F. GROUP & \\
\hline Highland area farmers from AMCOS & 1,245 & 125 farmers & \\
\hline Lowland area farmers from AMCOS & 1,059 & 106 farmers & \\
\hline Highland area farmers from Farmers' Group & 833 & 83 farmers & \\
\hline Lowland area farmers from Farmers' Group & 763 & 76 farmers & \\
\hline $\begin{array}{l}\text { Farmers who are members of AMCOS who } \\
\text { accessed agro inputs using income from } \\
\text { other sources }\end{array}$ & 1,097 & 110 & \\
\hline $\begin{array}{l}\text { Farmers who are members of farmers' } \\
\text { groups who accessed agro inputs using } \\
\text { income from other sources }\end{array}$ & 762 & 76 & \\
\hline $\begin{array}{l}\text { Farmers who are members of AMCOS who } \\
\text { accessed agro inputs through WRS credit } \\
\text { system }\end{array}$ & 1,496 & 150 & \\
\hline $\begin{array}{l}\text { Farmers who are members of farmers' } \\
\text { groups who accessed agro inputs through } \\
\text { WRS credit system }\end{array}$ & 1,033 & 103 & \\
\hline $\begin{array}{l}\text { Farmers who were in both groups i.e. } \\
\text { accessed agro inputs through WRS credit } \\
\text { system and using income from other sources }\end{array}$ & 491 & 49 & \\
\hline Total number of respondents (farmers) & 3,900 & 390 farmers & \\
\hline
\end{tabular}

Source: Yamane (1967) 